PF 2020 (75/1): 161-174

https://doi.org/10.32798/pf.655

\author{
MACIEJ GROCHOWSKI \\ Instytut Języka Polskiego PAN, Kraków \\ e-mail: maciej.grochowski@ijp.pan.pl \\ ORCID 0000-0002-1230-7005
}

\title{
OPERATORY LIMITACJI \\ O POSTACI SUPERLATYWU PRZYSŁÓWKA \\ W JEZYKU POLSKIM
}

\section{LIMITATORS IN THE SHAPE OF THE SUPERLATIVE OF ADVERB IN POLISH}

\begin{abstract}
It is possible to distinguish in Polish a special class of lexical units that have the shape of adverb superlatives, yet belong to the class of metapredicative operators. The paper discusses a subclass of them, namely limitators.

A limitator opens one syntactic position, primarily on its right side, for an expression implying the notion of quantity, number or measure; grammatical forms of the expressions filling this position are varied. Contrary to that, a superlative of adverbs opens up two positions, the first for a verb and the other for a prepositional phrase. The paper contains a detailed analysis of five homonymic units belonging both to the class of adverbs and to the class of limitators.
\end{abstract}

KEYWORDS: the contemporary Polish language, syntax, parts of speech, connotation, quantification

SŁOWA KLUCZOWE: współczesny język polski, składnia, części mowy, konotacja, kwantyfikacja

1.1. W literaturze z zakresu gramatyki języka polskiego przysłówek jako część mowy (leksem) charakteryzowany jest $w$ różny sposób. Eksponuje się jednak zawsze związek przysłówka z czasownikiem, przyjmując, że pierwszy jest podrzędnikiem drugiego, choć nie jest przez niego implikowany. Implikacja przysłówka motywowana znaczeniem poszczególnych leksemów czasownikowych (por. np. Piotr czuje się źle. Uroczystość trwała długo.) stanowi osobny problem. 
Zgodnie z konwencją terminologiczną klasycznego strukturalizmu przysłówek uważa się za człon syntaktyczny (syntaktem) konotujący kategorialnie czasownik i wchodzący z czasownikiem w relację dwustronną (Bühler 2004, Milewski 1965, Gołąb 1967, Zaron 2003). Teza, że przysłówek jest leksemem określającym również przymiotnik (Grzegorczykowa 1975, Laskowski 1998, Zaron 1993, 2003) nie jest już tak powszechnie aprobowana jak teza wcześniejsza (w tym artykule też nie jest), zwłaszcza od czasu podjęcia badań nad jednostkami należącymi do poziomów meta (będzie o tym mowa niżej). Charakterystyka przysłówka jako leksemu, który jest określany m.in. przez przysłówek, zawiera błędne koło bezpośrednie, musi być więc a priori odrzucona. W wielu pracach podkreśla się, że przysłówek nie wchodzi w zależność syntaktyczną z rzeczownikiem (Laskowski 1998, s. 57; Wróbel 1996, s. 57; Zaron 1993, s. 39; Grochowski 1986, s. 51; 1997, s. 24). Leksemy przysłówkowe przeciwstawia się na podstawie tego kryterium jednostkom innych klas, np. modalizatorom (Laskowski 1998) lub partykułom (Wróbel 1996, Grochowski 1986, 1997). Drugi człon opozycji zależy od proponowanej klasyfikacji leksemów.

1.2. Przysłówki są nieodmienne. Niektóre leksemy przysłówkowe podlegają stopniowaniu (Grzegorczykowa 1998, Karolak 1999). Stopniowanie jest operacją semantyczną, która polega na komunikowaniu różnic ilościowych między cechami obiektów lub stanów rzeczy. Inwariantem semantycznym komparatywu jest wynik porównania danej cechy w dwóch stanach rzeczy, nieidentycznych pod względem wielkości. Inwariantem semantycznym superlatywu jest wynik porównania danej cechy w co najmniej trzech stanach rzeczy, umożliwiający wybór tego stanu, w którym wielkość tej cechy jest większa lub mniejsza niż w pozostałych (Bałabaniak 2013, Jurkowski 1976, Laskowski 1977, Grochowski 2018).

Roman Laskowski (1998, s. 86) w GWJPM przyjął, że formy stopnia wyższego i najwyższego przymiotnika i przysłówka są odrębnymi leksemami, ponieważ różnią się składniowo i semantycznie od form stopnia równego. Jadwiga Wajszczuk (2010, s. 28) w najnowszej, znanej mi klasyfikacji leksemów polskich zaliczyła komparatywy przymiotników i przysłówków do klasy predykatów zależnych, czyli do takich syntaktemów, które mogą wchodzić na pozycje otwierane przez inne leksemy i równocześnie otwierać, z drugiej strony, nowe pozycje syntaktyczne. Kwalifikacja superlatywów byłaby na zasadzie analogii taka sama. Superlativus przysłówka konotuje składniowo frazę nominalną przyimkową i jako jej nadrzędnik wchodzi w relację dwustronną z wyrażeniem reprezentowanym przez określone leksemy przyimkowe (najczęściej $z$ / spośród + gen.) i formy określonych klas semantycznych rzeczowników, prymarnie denotujących nazwy zbiorowości. Np. 
(1) Piotr czyta najwolniej z całego rodzeństwa.

(2) Chile są najszybciej rozwijającym się państwem Ameryki Łacińskiej.

(3) Ewa najładniej się uśmiecha ze wszystkich dziewcząt w klasie.

(4) Kowalski najdłużej należał do partii spośród wszystkich jej działaczy.

1.3. Operatory metapredykatywne to według Jadwigi Wajszczuk (2010, s. 28) jedna z pięciu grup predykatów niezależnych, czyli takich syntaktemów, które otwierają pozycje syntaktyczne, ale nie wchodzą na pozycje otwierane przez inne leksemy. Autorka nie używa w swoim podziale terminu „operatory metapredykatywne”, posługuje się następującą opisową charakterystyką grupy: „Words of the type: bardzo, niemal, prawie, całkiem, zbyt, dość, około [stu], tuż [za płotem], etc. (intensifiers, limitators, approximators)". W pracach z zakresu teorii leksykografii, dotyczących jednostek funkcyjnych zwróciliśmy uwagę (Grochowski, Kisiel, Żabowska 2014, s. 27; 2018, s. 194), że pozycja otwierana przez operator metapredykatywny jest nacechowana semantycznie, a wyrażenia zdolne do występowania w tej pozycji są pod względem formalnym różne. Idąc za sugestią Wajszczuk wyodrębniamy w klasie tych operatorów operatory gradacji, aproksymacji i limitacji. Podział ten należy uważać za tymczasowy, ponieważ z klasy liczącej prawdopodobnie kilkaset jednostek zbadanych zostało zaledwie kilkadziesiąt. Operatory limitacji otwierają miejsce dla wyrażenia, które opisuje właściwość zajmującą wysokie lub niskie miejsce na danej skali, w porównaniu

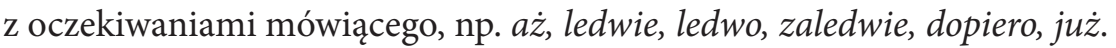

1.4. Przedmiotem tego artykułu jest kilkuelementowy zbiór jednostek, których kształt jest tożsamy z kształtem superlatywu przysłówka, a których właściwości składniowe i znaczenie wskazują na przynależność do innej klasy gramatycznej. Stawiam hipotezę, że jednostki o postaci najdalej, najmarniej, najmniej, najprędzej, najwyżej są operatorami metapredykatywnymi i reprezentują podklasę operatorów limitacji. Celem tego artykułu jest porównanie właściwości składniowych i semantycznych superlatywów przysłówka oraz wymienionych, homonimicznych z nimi, operatorów, a przede wszystkim uzasadnienie odrębności gramatycznej porównywanych leksemów. W drugiej części artykułu przedstawiam opisy wymienionych jednostek w sześciu słownikach ogólnych współczesnej polszczyzny, od SJPDor począwszy, a kończąc na WSJP. Porównuję sposoby hasłowania jednostek i ich kwalifikację gramatyczną. Nie analizuję szczegółowo definicji słownikowych ani ich nie oceniam, wymagałoby to koncentracji uwagi na metodach ustalania reprezentacji semantycznej jednostek funkcyjnych. Problem ten nie należy do tematyki tego artykułu.

2.1. Za punkt wyjścia analizy przyjmuję przykładowe wypowiedzenia, pochodzące z NKJP lub utworzone przeze mnie na wzór zarejestrowanych w NKJP, w których 
każdy z występujących dwukrotnie ciągów diakrytów raz jest użyty jako superlativus przysłówka, a drugi raz jako operator metapredykatywny. Ciąg najwyżej jest reprezentowany przez trzy wypowiedzenia, w ostatnim jest partykułą. Por.

(5) Nauczyciele zarabiają najmarniej ze wszystkich grup zawodowych. (NKJP)

(6) Do zachodu słońca pozostały jeszcze najmarniej trzy godziny. (NKJP)

(7) Ze wszystkich wędlin najprędzej zepsuł się baleron.

(8) Remont budynku rozpocznie się najprędzej w przyszłym roku.

(9) Ze wszystkich uczestników zebrania siedział najdalej od trybuny.

(10) Oddam ci wszystkie książki najdalej za miesiąc.

(11) Piotr zmienił się najmniej z twoich kolegów ze studiów.

(12) Przewiduję, że ten proces potrwa najmniej pięć lat.

(13) Ze wszystkich uczestników konkursu Nowaka oceniono najwyżej.

(14) Poopalam się na plaży najwyżej trzy godziny.

(15) Czego mi zawracasz głowę głupimi lekcjami? Raz możemy nie odrobić. Najwyżej złapiemy dwóje. (NKJP)

Wypowiedzenia (5), (7), (9), (11), (13), w których ciąg o postaci superlatywu przysłówka pełni swoją prymarną funkcję, odpowiadającą formie, łączy to, że jednostki przysłówkowe wchodzą w zależność dwustronną, odpowiednio z formą czasownika, do której zostały dodane, i z frazą nominalną przyimkową w genetiwie (z przyimkiem $z(e)$ ), dla której otwierają pozycję syntaktyczną. Potwierdzeniem postulowanej zależności jest redukcja przysłówka powodująca dewiację poszczególnych wypowiedzeń. Por. (5), (7), (9), (11), (13) z podanymi niżej (16), (17), (18), (19), (20):

(16) *Nauczyciele zarabiają ze wszystkich grup zawodowych.

(17) ${ }^{*}$ Ze wszystkich wędlin zepsuł się baleron.

(18) *Ze wszystkich uczestników zebrania siedział od trybuny.

(19) *Piotr zmienił się z twoich kolegów ze studiów.

(20) ${ }^{\star} Z$ e wszystkich uczestników konkursu Nowaka oceniono.

Są one dewiacyjne syntaktycznie, co ma również swoje konsekwencje semantyczne (Grochowski 2008). Nowe wypowiedzenia są nieinformatywne. Odbiorca takich wypowiedzeń, a w każdym razie rodzimy użytkownik języka, jest zdolny do interpolowania jednostek mających postać superlatywu przysłówka, interpolacja powoduje jednak zmianę treści wypowiedzeń wyjściowych. Głębsze są konsekwencje redukcji przysłówka najdalej z wypowiedzenia (18). Przysłówek dale$k o$ otwiera pozycję dla frazy wprowadzanej przez przyimek od, a ta właściwość składniowa jest dziedziczona przez formę superlatywu (Węgiel 2000, s. 176). Odizolowanie frazy z ciągiem od od jej podstawy przysłówkowej powoduje, że nie da się powiązać tej frazy bezpośrednio z czasownikiem. 
Wspólną cechą superlatywów przysłówka w analizowanych wypowiedzeniach jest zmienność pozycji linearnej tych jednostek względem czasownika. Dopuszczalna jest zarówno ich antepozycja (bezpośrednia i pośrednia), jak i postpozycja (bezpośrednia i pośrednia). Również szyk frazy z przyimkiem $z(e)$ względem przysłówka jest zmienny. Może ona występować w bezpośredniej i pośredniej antepozycji albo postpozycji.

2.2. W wypowiedzeniach (6), (8), (10), (12), (14) ciąg o postaci superlatywu przysłówka nie jest przysłówkiem i nie wchodzi w zależność składniową z formą czasownikową. Świadczy o tym redukcja tego ciągu niemająca wpływu na strukturę składniową poszczególnych wypowiedzeń. Por. wypowiedzenia zredukowane:

(21) Do zachodu słońca pozostały jeszcze trzy godziny.

(22) Remont budynku rozpocznie się w przyszłym roku.

(23) Oddam ci wszystkie książki za miesiąc.

(24) Przewiduję, że ten proces potrwa pięć lat.

(25) Poopalam się na plaży trzy godziny.

Czasowniki tworzące badane wypowiedzenia wchodzą w zależność składniową z frazami nominalnymi, przyimkowymi (22), (23), lub bezprzyimkowymi (21), (24), (25), implikującymi pojęcie ilości sensu largo, mające wykładniki w postaci liczebnika i/lub rzeczownika. Frazy te wypełniają pozycje syntaktyczne otwierane przez czasownik, por. (21), (22), (24), reprezentują więc argumenty w danej strukturze predykatowo-argumentowej, bądź są do czasownika dodane, stanowiąc części odrębnych struktur predykatowo-argumentowych, por. (23), (25). Rozstrzygnięcie tego, jaki jest status danej frazy w danym wypowiedzeniu wymaga analizy struktury syntaktyczno-semantycznej poszczególnych czasowników, a to nie stanowi celu tego artykułu.

Ciągi o postaci superlatywu przysłówka w wypowiedzeniach (6), (8), (10), (12), (14) są odrębnymi leksemami należącymi do klasy operatorów metapredykatywnych, do subklasy operatorów limitacji. Otwierają one, prymarnie prawostronnie, pozycję syntaktyczną dla wyrażeń nacechowanych semantycznie. Wyrażenia te, o czym już była mowa, są zróżnicowane składniowo. Fakt, że występują one w pozycji konotowanej przez operatory metapredykatywne, można potwierdzić w wyniku redukcji tych wyrażeń, powodującej dewiację syntaktyczną wypowiedzeń, mającą również swoje konsekwencje semantyczne. Por.

(26) ${ }^{*}$ Do zachodu słońca pozostały jeszcze najmarniej.

(27) ${ }^{*}$ Remont budynku rozpocznie się najprędzej.

(28) * Oddam ci wszystkie książki najdalej.

(29) ${ }^{\star}$ Przewiduję, że ten proces potrwa najmniej.

(30) ${ }^{\star}$ Poopalam się na plaży najwyżej. 
Omawiane operatory metapredykatywne występują z reguły w bezpośredniej antepozycji względem konotowanych przez nie fraz. Taki szyk operatorów można by nazwać zapewne neutralnym. Niemniej jednak za interpretacją postpozycji jako szyku wtórnego operatorów nie przemawiają żadne relewantne argumenty. Jedynie intuicja rodzimego użytkownika skłania do umieszczenia akcentu bardziej na postpozycyjnym operatorze niż na antepozycyjnym.

Jeden $\mathrm{z}$ wymienionych wcześniej leksemów homonimicznych $\mathrm{w}$ stosunku do superlatywu przysłówka, najwyżej, por. (15), należy do klasy partykuł. Zgodnie z przyjętym rozumieniem tego terminu, partykuła to operator metatekstowy otwierający jedną pozycję dla rematu wypowiedzenia, nienacechowaną gramatycznie ani semantycznie, kookurujący z wyrażeniami wypełniającymi tę pozycję i komentujący remat wypowiedzenia (szerzej w: Grochowski, Kisiel, Żabowska 2014, s. 26; 2018, s. 192). O opisie jednostek o postaci najwyżej w słownikach będzie jeszcze mowa w punkcie 3.6.

3.1. Badane tutaj jednostki homonimiczne niemal w każdym słowniku ogólnym współczesnej polszczyzny są opisywane inaczej. Jednostki pełniące funkcję superlatywu przysłówka z reguły nie stanowią odrębnych haseł. Są często, ale nie zawsze wymieniane, a tym bardziej nie zawsze ilustrowane przykładami, w artykułach hasłowych wprowadzanych przez formę pozytywu przysłówka. Omawiane tu operatory metapredykatywne są wyróżniane jako odrębne hasła w WSJP, dlatego też słownik ten może być dobrym punktem wyjścia przy porównywaniu z wcześniejszymi słownikami ogólnymi, mianowicie SJPDor, SJPSz, USJP, ISJP i SWJP.

3.2. Jednostka najmarniej jako operator metapredykatywny limitacji (notabene, nie ma jej w tym znaczeniu w moim idiolekcie, opieram się więc tylko na przykładach zarejestrowanych w całym NKJP, a jest ich zaledwie 118) jest notowana tylko w WSJP, który objaśnia ją za pomocą następującej definicji (akceptowalnej):

'wielkość tego, o czym mowa, jest taka, że to, co mówi nadawca, to najmniejsza jego zdaniem możliwa wartość, chociaż sądzi, że może być większa'.

Operator otwiera pozycję syntaktyczną dla frazy zawierającej wyrażenie liczbowe, może być ono reprezentowane przez jednostkę lub konstrukcję należącą do różnych części mowy; najczęściej jest to liczebnik i rzeczownik. Por. np.

(31) Wyprawka pierwszoklasisty to najmarniej czterysta złotych. (NKJP)

(32) $\mathrm{Na}$ „malucha” na przedpłaty czekało się najmarniej pięć lat. (NKJP)

(33) Nikogo nie ma w redakcji, bo śpimy najmarniej do południa. (NKJP)

WSJP trafnie eliminuje ze zbioru elementów zdolnych do zajmowania pozycji konotowanej przez operator najmarniej wyrażenia „nazywające maksymalną liczebność obiektów typu wszyscy, każdy". Z omawianym operatorem kontrastuje 
superlativus przysłówka, konotujący kategorialnie czasownik, jak np. w (34), (35); por. też z (5):

(34) Nawet najmarniej napisana książka na ten temat robi na mnie ogromne wrażenie. (NKJP)

(35) Na tym tle najmarniej wypadała Magda. Zmartwiona, niezorganizowana, chwiejąca się niepewnie w niewygodnym obuwiu. (NKJP)

3.3. Jednostka najprędzej jest notowana tylko w WSJP, który kwalifikuje ją gramatycznie jako operator metapredykatywny limitacji i objaśnia za pomocą definicji: 'to, o czym mowa, nie wydaje się możliwe i nadawca mówi, że nie można powiedzieć niczego więcej o tym niż to, co mówi i że nawet to, co mówi, nie jest pewne’.

W innych słownikach ogólnych współczesnej polszczyzny, od SJPDor począwszy, nie jest rejestrowana jednostka o postaci najprędzej nawet jako ilustracja superlatywu przysłówka. NKJP podaje ogółem 2628 przykładów wypowiedzeń zawierających ciąg najprędzej, w tym też reprezentujące (w mojej ocenie) operator metapredykatywny limitacji. Por. np.

(36) Główny ideolog partii Susłow powiedział mu w rozmowie, że książka ukaże się najprędzej za dwieście lat. (NKJP)

(37) Nowe rozporządzenie zacznie obowiązywać najprędzej w styczniu przyszłego roku. (NKJP)

(38) Wyniki badań krwi będą znane najprędzej jutro. (NKJP)

W konotowanej przez tę jednostkę, prymarnie prawostronnej, pozycji syntaktycznej występują frazy nominalne i adwerbialne. Z wypowiedzeniami zawierającymi operator limitacji najprędzej kontrastują wypowiedzenia z homonimicznym superlatywem przysłówka:

(39) Dziewczyna pierwsza zaczęła sypać w czasie przesłuchań, najprędzej spośród wszystkich przesłuchiwanych okazała skruchę i dostała niższy wyrok. (NKJP)

(40) Można o nim powiedzieć, że powstał najprędzej ze wszystkich pomników polskich, a może i świata. (NKJP)

(41) Wśród kobiet triumfowała Maria Michta, a spośród mężczyzn najprędzej tę odległość pokonał Józef Pszczółka. (NKJP)

3.4. Jednostka najdalej stanowi osobne hasło w WSJP i w SWJP, w pierwszym słowniku jest operatorem metapredykatywnym limitacji, a w drugim przysłówkiem. W SJPDor, SJPSz i USJP najdalej jest rejestrowane jako jedno ze znaczeń przysłówka daleko, reprezentowane wyłącznie przez formę stopnia najwyższego. Głównym komponentem semantycznym definicji najdalej w pięciu wymienionych słownikach jest 'nie później niż', a jako bliskoznacznik tego wyrażenia podają one najpóźniej. 
ISJP nie wyróżnia jednostki najdalej, podaje tylko dwa przykłady jej użycia, ilustrujące znaczenie przysłówka daleko (bez względu na formę stopnia), wskazujące na odległość czasową; por. „Jeżeli jakieś zdarzenie lub jakiś stan są daleko, to znaczna odległość w czasie dzieli je od chwili, w której lub o której mówimy." Z definicją tą nie są skorelowane wypowiedzenia z najdalej, które mają ją egzemplifikować:

(42) Musicie być gotowi najdalej za kwadrans. (ISJP)

(43) Jutro, a najdalej pojutrze, musimy jechać. (ISJP)

Towarzyszący definicji opis gramatyczny daleko jest nieadekwatny do właściwości jednostki najdalej. Nie ma ona tych samych cech co formy stopnia równego i wyższego przysłówka. W wypowiedzeniach (42), (43) nie jest przysłówkiem, nie wchodzi bowiem $w$ relację syntaktyczną z czasownikiem, tylko odpowiednio $\mathrm{z}$ frazą nominalną przyimkową i frazą adwerbialną. W przytoczonym znaczeniu antonimem daleko nie jest blisko.

Jak wynika z przykładów słownikowych i korpusowych, operator limitacji o postaci najdalej konotuje frazy temporalne (Laskowski 2003, 2005). Są one formalnie zróżnicowane, mają postać grup nominalnych, z różnymi przyimkami, i grup adwerbialnych. Por. np.

(44) Choroba jest nieuleczalna. Najdalej po kilkunastu miesiącach prowadzi do zejścia śmiertelnego. (NKJP)

(45) Oddam panu wszystko razem najdalej za miesiąc. (NKJP)

(46) Cechy dziedziczne wracają $\mathrm{w}$ trzecim, najdalej w czwartym pokoleniu. (NKJP)

(47) Czekali na rozkazy. Najdalej w ciągu ośmiu godzin od ich wydania znajdą się w Nowym Jorku. (NKJP)

(48) Ja tu zostanę do kwietnia najdalej, a potem nad morze. (NKJP)

(49) Najdalej pojutrze wjadą tu dalsze piękne wozy pod następne, właśnie wykańczane wiaty. (NKJP)

3.5. Ciąg najmniej we wszystkich słownikach ogólnych współczesnej polszczyzny, z wyjątkiem ISJP, stanowi osobne, przynajmniej jedno, hasło. W WSJP jest kwalifikowany jako operator metapredykatywny limitacji i objaśniony za pomocą następującej definicji: 'wielkość tego, o czym mowa, jest taka, że zajmuje najniższe miejsce na wymaganej skali'. Ilustrują ją m.in. przykłady wypowiedzeń

(50) (...) dostanę nie cztery, nie pięć, ale najmniej siedem drewnianych skrzynek, a w ogóle do zimy jeszcze daleko, zresztą, kto wie, może mieć łagodny przebieg. (NKJP)

(51) A i to potrwa najmniej do tysiąc dziewięćset siedemdziesiątego roku. (NKJP)

(52) Madzię złapali przed szturmem. Wiozła dla nas pieniądze z Łodzi i inne jeszcze rzeczy. Sprawa beznadziejna. Najmniej pięć lat. (NKJP) 
Omawiany operator konotuje wyrażenia liczbowe z wyjątkiem „nazywających maksymalną liczebność obiektów typu wszyscy, każdy".

W SJPDor i w SJPSz hasło najmniej reprezentuje dwa znaczenia, mianowicie stopień najwyższy od mało oraz 'nie mniej niż, przynajmniej', bez kwalifikacji gramatycznej. USJP wyróżnia trzy hasła homonimiczne o postaci najmniej, pierwsze dwa, odsyłaczowe, mają reprezentować stopień najwyższy od I mało i II mało. Drugi odsyłacz jest bez pokrycia, jako że II mało jako zaimek liczebny nieokreślony nie podlega stopniowaniu, nie może więc mieć formy stopnia najwyższego. Hasło III najmniej jest objaśnione za pomocą takiej oto definicji: 'partykuła komunikująca, że ilość, liczba lub miara czegoś jest nie mniejsza od wymienionej i że może być większa; przynajmniej.' Odzwierciedla ona znaczenie operatora limitacji wyróżnione w WSJP, co potwierdzają też przykłady podane w USJP:

(53) Konferencja potrwa najmniej cztery godziny.

(54) Opłatę za wodę podniosą najmniej dwukrotnie.

Zamieszczony na końcu artykułu hasłowego komentarz dotyczący łączliwości opisywanej jednostki nie potwierdza jej przynależności do klasy partykuł (por. 2.2.). W komentarzu tym jest bowiem powiedziane, że „partykuła (...) jest dodawana do liczebników, wyrażeń pochodzących od liczebnika, rzeczowników nazywających liczbę, ilość lub miarę".

SWJP zalicza jednostkę najmniej do klasy modulantów. Termin ten, wprowadzony przez Jodłowskiego (1976: 20), ma nazywać wyrazy, które nie są składnikami wypowiedzenia ani wskaźnikami zespolenia i nie determinują składników, którym towarzyszą, lecz jedynie „zaznaczają pozakonstrukcyjne elementy wypowiedzenia”. Definicja najmniej w SWJP stara się odzwierciedlić dość ściśle znaczenie omawianego operatora; por. 'z określeniami liczby, ilości, miary czegoś: tyle na pewno, a spodziewam się, że więcej; co najmniej’.

ISJP ogranicza się do utożsamienia znaczenia jednostki najmniej ze znaczeniem jednostki przynajmniej, mimo istotnych różnic w kwalifikacji gramatycznej jednostek. Pierwsza została zaliczona do przysłówków dodawanych do czasownika (wbrew podanym przykładom), druga do partykuł (o opozycji co najmniej - przynajmniej zob. w: Grochowski 2014).

Por. przykłady użycia najmniej jako operatora limitacji:

(55) Leje - rzekł - będzie najmniej trzydniówka. (NKJP)

(56) Kara ograniczenia wolności trwa najmniej miesiąc, najwyżej rok, poniżej roku wymierza się ją w miesiącach. (NKJP)

(57) Panna Asmare urodziła się najmniej ćwierć wieku temu i jak na afrykańskie standardy była już panną lekko podstarzałą. (NKJP) 
3.6. W WSJP są wyróżnione dwie jednostki homonimiczne o postaci najwy$\dot{z} e j$, pierwsza uznana za przysłówek, mająca znaczenie 'ostatecznie', druga uznana za dwuznaczną jednostkę funkcyjną, w pierwszym znaczeniu kwalifikowana jest jako operator metapredykatywny aproksymacji, a w drugim jako partykuła wyróżniająca. Nie wszystkie cytaty ilustrujące te rozróżnienia są trafnie dobrane. Jednostce najwyżej I, niesłusznie uznanej za przysłówek, należy przypisać znaczenie, które ma partykuła $w$ ostateczności, a nie ostatecznie. W Słowniku gniazdowym partykuł polskich (Grochowski, Kisiel, Żabowska 2014, s. 187-189, 195-197) uznaliśmy wymienione partykuły za nierównoznaczne. Pierwszej przyporządkowaliśmy następującą reprezentację semantyczną: 'nadawca mówi o $\mathrm{T}$, że jeżeli nic innego, co było brane pod uwagę i uważane za lepsze, nie będzie możliwe, to R' (tamże, s.195). Odzwierciedla też ona przekonująco znaczenie jednostki najwyżej I w cytowanym w WSJP wypowiedzeniu

(58) Chyba jednak lepiej wypić, myślę, najwyżej potem zwymiotuję. (NKJP)

Wyodrębnienie dwóch znaczeń jednostki najwyżej II nie jest słuszne. Por. np. cytaty ilustrujące w WSJP dwa jej inne znaczenia:

(59) (...) trwało to wszystko jednak krótko, parę dni, najwyżej tydzień, gdy wreszcie Ludka pojawiła się znów wymalowana, wyelegantowana, zaczepna i pełna werwy.

(60) Broń była nowiutka. Najwyżej raz przestrzelana. Z pełnymi magazynkami.

Definicje tych znaczeń, ujęte co prawda w odmiennych konwencjach terminologicznych i redakcyjnych, łączy wspólny komponent treściowy ograniczający zakres tego, o czym mowa do 'nie więcej niż. Zgodnie z zasadą niemnożenia bytów należałoby wydzielić jedno znaczenie jednostki najwyżej II i zakwalifikować ją do klasy operatorów metapredykatywnych limitacji. Por. ponadto:

(61) Ściana z mansardowym oknem miała najwyżej osiemdziesiąt centymetrów wysokości. (NKJP)

(62) Prawo cywilne dopuszcza najwyżej pięciokrotne zawieranie małżeństwa. (NKJP)

(63) Ścieżkami ku górze posuwało się najwyżej kilkanaście osób. (NKJP)

Uzasadnione byłoby wyodrębnienie superlatywu przysłówka o postaci najwyżej, którego w WSJP brakuje. Przykłady użycia tej jednostki można znaleźć pod hasłem wysoko.

W SJPDor jednostki o postaci najwyżej - z relewantnym dla operatorów limitacji komponentem semantycznym 'nie więcej niż' - są hasłowane dwukrotnie. W znaczeniu 3. hasła wysoko omawianą jednostkę rejestruje się wśród dwuznacznych związków frazeologicznych. Podane są dwa tzw. odcienie znaczeniowe najwyżej (wyróżnia i definiuje je tak samo SJPSz):

a) 'nie więcej niż, tylko', np. 
(64) Z tego, co zostało po ojcu, będą mogli żyć najwyżej parę lat.

b) 'w ostatecznym (najgorszym lub najlepszym) razie; ostatecznie', np.

(65) Najwyżej nie wyprawi się świąt.

W artykule hasłowym wprowadzonym przez najwyżej podane są dwa znaczenia jednostki: 1. Stopień najwyższy od wysoko, 2. 'nie więcej niż; w najlepszym razie (często w tym samym znaczeniu co najwyżej)'; np.

(66) (...) pobędę tu chyba najwyżej dwa tygodnie.

(67) Mnie kawa szkodzi, mogę najwyżej jedną filiżankę.

Definicja drugiego znaczenia stanowi połączenie fragmentów dwóch definicji jednostki zamieszczonych pod hasłem wysoko w znaczeniu 3.

USJP podaje dwa hasła homonimiczne o postaci najwyżej. W pierwszym wyróżnia się dwa znaczenia - stopnia najwyższego od wysoko oraz 'w ostatecznym razie, ostatecznie’. Drugie, bez kwalifikacji gramatycznej, odpowiada przypuszczalnie omawianemu już znaczeniu partykuły $w$ ostateczności. Drugie hasło homonimiczne, zaliczone przez USJP do partykuł, ma właściwości wyróżnionego już wcześniej operatora limitacji. Potwierdzają to cytowane przykłady wypowiedzeń oraz komentarz na końcu artykułu hasłowego, informujący o ograniczeniach użycia jednostki: „jest dodawana do liczebników, wyrażeń pochodzących od liczebnika, rzeczowników nazywających liczbę, ilość lub miarę".

W SWJP podane są również dwa hasła homonimiczne o postaci najwyżej, reprezentujące jednostki kwalifikowane jako przysłówek i modulant. Pierwsza jednostka ma znaczenie 'z określeniami liczby, ilości, miary czegoś: nie więcej niż', odpowiadające omawianemu operatorowi limitacji. Druga - zdefiniowana za pomocą formuły 'tym słowem mówiący wyraża, że jego zdaniem nie stanie się nic gorszego niż to, o czym mowa; w najgorszym razie' - reprezentuje przypuszczalnie charakteryzowaną już partykułę $w$ ostateczności.

ISJP zamieszcza jednostkę najwyżej w artykule hasłowym wprowadzonym przez wysoko i opisuje ją jako dwuznaczną. W pierwszym znaczeniu, kwalifikowana jako partykuła, jest używana „aby określić maksymalną wielkość, zakres lub natężenie czegoś”. Znaczenie to odpowiada operatorowi limitacji. W drugim znaczeniu, kwalifikowana jako przysłówek w stopniu najwyższym, dodawany do czasownika, ma być synonimem jednostki ostatecznie.

4. Wspólną cechą składniową operatorów metapredykatywnych limitacji o postaci superlatywu przysłówka jest to, że otwierają one, prymarnie prawostronnie, jedną pozycję syntaktyczną dla wyrażeń implikujących pojęcie ilości sensu largo, ściślej mówiąc określających ilość, liczbę, miarę bądź granicę czasu. Formalnie wyrażenia te są zróżnicowane, mają postać fraz nominalnych przyimkowych 
i bezprzyimkowych, a także fraz adwerbialnych. W przeciwieństwie do superlatywów przysłówka operatory limitacji nie wchodzą w relację z czasownikiem ani nie otwierają pozycji syntaktycznej dla frazy nominalnej z przyimkiem $z$ / spośród (+ gen.).

Porównanie artykułów hasłowych poświęconych operatorom metapredykatywnym limitacji i ich homonimom w sześciu słownikach ogólnych współczesnej polszczyzny pozwala na postawienie tezy, że z punktu widzenia gramatyki najdokładniejsze opisy badanych jednostek funkcyjnych i odpowiadające współczesnemu stanowi wiedzy o tych jednostkach zawiera Wielki słownik języka polskiego PAN. Każdy opis słownikowy, w tym również opisy omówione w tym artykule, można poprawić; nie ma opisów idealnych.

\section{Skróty}

GWJPM - Gramatyka współczesnego języka polskiego. Morfologia, red. R. Grzegorczykowa, R. Laskowski, H. Wróbel, Warszawa: Wydawnictwo Naukowe PWN 1998, wyd. 2;

WSJP - Wielki słownik języka polskiego PAN, red. P. Żmigrodzki, Kraków 2007-2018. http:// www.wsjp.pl/.

\section{Bibliografia}

Bałabaniak, D. (2013). Polskie intensyfikatory leksykalne na tle wyrażeń gradacyjnych. Opole: Uniwersytet Opolski.

Bühler, K. (2004). Teoria języka. O językowej funkcji przedstawiania. Tłum. J. Koźbiał, Kraków: Universitas.

Gołąb, Z. (1967). Próba klasyfikacji syntaktycznej czasowników polskich (na zasadzie konotacji), Biuletyn PTJ, 25, 3-43.

Grochowski, M. (1986). Polskie partykuły. Składnia, semantyka, leksykografia. Wrocław: Ossolineum.

Grochowski, M. (1997). Wyrażenia funkcyjne. Studium leksykograficzne. Kraków: Instytut Języka Polskiego PAN.

Grochowski, M. (2008). Rola dewiacji w uzasadnianiu hipotez semantycznych. Wprowadzenie do problematyki, Biuletyn PTJ, 64, 25-36.

Grochowski, M. (2014). W poszukiwaniu różnicy znaczeń (na przykładzie opozycji co najmniej - przynajmniej). W: L. Bednarczuk, A. Bochnakowa, S. Widłak (red.), Linguistique romane et linguistique indo-européenne. Mélanges offerts à Witold Mańczak à loccasion de son 90e anniversaire (251-258). Kraków: Polska Akademia Umiejętności. 
Grochowski, M. (2018). Asymetria semantycznych i gramatycznych ograniczeń stopniowania przymiotników w języku polskim. W: Z. Greń (red.), Z polskich studiów slawistycznych, seria 13, tom 2, Językoznawstwo (83-92). Poznań: UAM.

Grochowski, M., Kisiel, A., Żabowska, M. (2014). Słownik gniazdowy partykuł polskich. Kraków: Polska Akademia Umiejętności.

Grochowski, M., Kisiel, A., Żabowska, M. (2018). Zasady opisu jednostek funkcyjnych w WSJP PAN. W: P. Żmigrodzki (red.), Wielki słownik języka polskiego PAN. Geneza, koncepcja, zasady opracowania (191-204). Kraków: Instytut Języka Polskiego PAN.

Grzegorczykowa, R. (1975). Funkcje semantyczne i składniowe polskich przysłówków. Wrocław: Ossolineum.

Grzegorczykowa, R. (1998). Przysłówek. W: GWJPM, 524-534.

Jodłowski, S. (1976). Podstawy polskiej składni. Warszawa: PWN.

Jurkowski, M. (1976). Semantyka i składnia wyrażeń gradacyjnych (w językach wschodniosłowiańskich). Katowice: Uniwersytet Śląski.

Karolak, S. (1999). Stopniowanie. W: K. Polański (red.), Encyklopedia językoznawstwa ogólnego (559-561). Wrocław: Ossolineum.

Laskowski, R. (1977). Od czego lepszy jest lepszy? Język Polski, 57, 323-334.

Laskowski, R. (1998). Zagadnienia ogólne morfologii. W: GWJPM, 27-86.

Laskowski, R. (2003). Präpositionale Ausdrücke mit temporaler Funktion im Polnischen. W: G. Hentschel, T. Menzel (red.), Präpositionen im Polnischen (193-226). Oldenburg: BIS.

Laskowski, R. (2005). Temporalne frazy przyimkowe o funkcji prospektywnej i retrospektywnej. W: M. Grochowski (red.), Przysłówki i przyimki. Studia ze składni i semantyki języka polskiego (209-225). Toruń: Uniwersytet Mikołaja Kopernika.

Milewski, T. (1965). Językoznawstwo. Warszawa: PWN.

Wajszczuk, J. (2010). Functional class (so called „part of speech”) assignment as a kind of meaning-bound word syntactic information, Cognitive Studies / Études Cognitives, $10,15-33$.

Węgiel, M. (2000). Opis syntaktyczny przysłówka na przykładzie leksemu daleko, Polonica, 20, 171-185.

Wróbel, H. (1996). Nowa propozycja klasyfikacji syntaktycznej polskich leksemów. W: H. Wróbel (red.), Studia z leksykologii i gramatyki języków słowiańskich (53-60). Kraków: Instytut Języka Polskiego PAN.

Zaron, Z. (1993). Uwagi o miejscu przysłówka w strukturze zdania, Folia Philologica Macedono-Polonica, 2, 29-41.

Zaron, Z. (2003). Funkcjonalna klasyfikacja leksemów polskich (kolejna propozycja). W: M. Gębka-Wolak, I. Kaproń-Charzyńska, M. Urban (red.), Studia z gramatyki i leksykologii języka polskiego (179-188). Toruń: Uniwersytet Mikołaja Kopernika. 
ABSTRAKT: Można wyróżnić w języku polskim jednostki leksykalne o postaci superlatywu przysłówka należące do klasy operatorów metapredykatywnych. W artykule jest omawiana jedna z podklas tych operatorów, mianowicie operatory limitacji.

Operator limitacji otwiera jedną pozycję syntaktyczną, prymarnie prawostronnie, dla wyrażenia implikującego pojęcie ilości, liczby lub miary. Formy gramatyczne wyrażeń wypełniających tę pozycję mogą być różne. Superlativus przysłówka natomiast otwiera dwie pozycje, jedną dla czasownika, a drugą dla frazy przyimkowej. Artykuł zawiera szczegółową analizę pięciu homonimicznych jednostek, należących zarówno do klasy przysłówków, jak i do klasy operatorów limitacji. 